Kong. Res. J. 4(2): 24-31, 2017

ISSN 2349-2694

Kongunadu Arts and Science College, Coimbatore.

\title{
QUALITATIVE AND QUANTITATIVE ANALYSIS OF PHYTOCHEMICALS AND IN VITRO ANTIOXIDANT ASSAYS IN THE TUBER OF SOLENA AMPLEXICAULIS (LAM.) GANDHI. (CUCURBITACEAE)
}

\author{
Karthika, K*., S. Jamuna and S. Paulsamy \\ PG and Research Department of Botany, Kongunadu Arts and Science College, Coimbatore - 641029. \\ *E.mail: karthika1431989@gmail.com
}

\begin{abstract}
Most of the traditional medicinal plants in India are not scientifically validated. Scientific evaluation of medicinal property along with traditional knowledge is essential to obtain effective drugs for commercial purpose. Solena amplexicaulisbelongs to the family, Cucurbitaceae, a traditional medicinal plant species of Tamil Nadu, India is being prescribed to cure various diseases. In this study, the objective was to investigate the qualitative and quantitative determinations of certain phytochemicals and in vitro antioxidant capabilities of various alcoholic and aqueous tuber extracts of $S$. amplexicaulisby adapting standard procedures. In all the assays methanolic tuber extract registered significantly high amount of secondary metabolites and also it effectively scavenge the free radicals in a concentration dependent manner than the other extracts. These results were compared with synthetic (BHA and BHT) as well as natural antioxidants (rutin and quercetin). The outcome of the study revealed most valuable information and also supports the continued sustainable use of this species in traditional systems of medicine.
\end{abstract}

Keywords: Solena amplexicaulis, Cucurbitaceae, phytochemical analysis, antioxidant properties.

\section{INTRODUCTION}

Herbal medicines are in huge demand in the developing countries for primary health care because of their effectiveness, safety and lesser side effects. Now traditional medicine is being reevaluated by extensive research on different plant species and their therapeutic principles. The phytochemical compounds play a significant role in biological functions. There is growing interest in correlating the bioactive components of a medicinal plant with its pharmacological activity. Based on accumulative evidence, in recent decades tremendous interest has considerably increased in finding out the natural substances especially from plants (Dezfuli et al., 2014; Servili et al., 2014). Antioxidant compounds in food plays an important role as a health protecting factor. The main characteristic of an antioxidant is its ability to trap free radicals. These free radicals may oxidize nucleic acids, proteins, lipids and DNA that can initiate degenerative diseases (Carlsen et al., 2010).

Solena amplexicaulis is commonly called as creeping cucumber, belongs to the family, Cucurbitaceae mainly distributed in the dry deciduous forests of southern India (Matthew, 1983; Paulsamy and Karthika, 2014). The traditional healers are prescribing the tubers of this species as astringent, appetizer, carminative, cardiotonic, digestive, diuretic, expectorant, invigorating, purgative, stimulant, sour and thermogenic (Dhananjay, 2006). The whole plant is a potential source of natural antioxidant (Venkateshwaralu et al., 2011; Karthika et al., 2012) and antiinflammatory agent (Arun et al., 2011). It is recognized as CNS active, diuretic, febrifuge and hypothermic (Dhananjay, 2006). Crude leaf juice is used to cure jaundice (Mohammed et al., 2011). Raw unripe fruits are eaten to strengthen the body (Jeyaprakash et al., 2011). The decoction of the root is administered orally to cure stomachache (Abdolbaset et al., 2011). The seeds are used as purgative (Jeyaprakash et al., 2011).

However, no study on antioxidant properties has been available for the tuber of this species. To address this lacuna, an attempt has been made to investigate the qualitative and quantitative phytochemical analysis and certain in vitro antioxidant activities of successive extracts (hexane, benzene, chloroform, methanol and water) from the tuber of S. amplexicaulis. These antioxidants values were compared with commercially available synthetic as well as natural antioxidants.

\section{MATERIALS AND METHODS}

\subsection{Chemicals and reagents}

2,2-diphenyl-1-picrylhydrazyl (DPPH•), 2,2'azinobis-(3-ethylbenzothiazoline-6-sulfonic acid) $\left(\right.$ ABTS $\left.^{*+}\right)$, 6-hydroxy-2,5,7,8-tetramethylchroman-2carboxylic acid (Trolox), diosgenin (DE), butylatedhydroxyanisole (BHA), butylated hydroxytoluene (BHT), ferric chloride $\left(\mathrm{FeCl}_{3}\right)$, ferrous ammonium sulphate $\left(\mathrm{Fe}\left(\mathrm{NH}_{4}\right)_{2}\left(\mathrm{SO}_{4}\right)_{2} \cdot 6 \mathrm{H}_{2} \mathrm{O}\right)$, 
Folin-Ciocalteu reagent, gallic acid, polyvinyl polypyrrolidone (PVPP), potassium ferricyanide $\left(\mathrm{K}_{3} \mathrm{Fe}(\mathrm{CN})_{6}\right)$, potassium persulfate $\left(\mathrm{K}_{2} \mathrm{~S}_{2} \mathrm{O}_{8}\right)$, quercetin, sodium carbonate $\left(\mathrm{Na}_{2} \mathrm{CO}_{3}\right)$, sodium nitroprusside $\left(\mathrm{Na}_{2}\left[\mathrm{Fe}(\mathrm{CN})_{5} \mathrm{NO}\right]\right)$, trichloroacetic acid (TCA), hydrogen peroxide $\left(\mathrm{H}_{2} \mathrm{O}_{2}\right)$, L-ascorbic acid (vitamin $\mathrm{C}$ ) and $\beta$-carotene were purchased from Himedia (Mumbai, India). All other reagents and solvents used were of analytical grade.

\subsection{Plant material}

The fresh tuber parts of $S$. amplexicaulis were collected from the thorny scrub jungles of Madukkarai, Coimbatore district, Tamil Nadu, India during the month of April, 2014. The authenticity of the plant was confirmed by comparing with the reference specimen (Vide No: CPS 313) preserved at Botanical Survey of India, Southern Circle, Coimbatore. The samples were cleaned, washed with copious amount of water, shade dried and coarsely powdered in a Willy Mill to 60 mesh size (Nippon Electricals, Chennai, India) for extraction.

\subsection{Preparation of extracts}

About $50 \mathrm{~g}$ of powdered plant material was extracted $(50 \mathrm{~g} / 250 \mathrm{~mL})$ in a soxhlet extractor for 8 to $10 \mathrm{~h}$, sequentially with the alcoholic solvents viz., hexane, benzene, chloroform and methanol and aqueous. Then the extracts were evaporated to dryness and stored at $4{ }^{\circ} \mathrm{C}$ in storage vials for experimental use.

\subsection{Qualitative estimations}

All the extracts were subjected to preliminary phytochemical analysis followed by the methods of Harborne (1998) and Trease and Evans (2002).

\subsection{Quantitative estimations}

Major non-enzymic antioxidants of the plant extracts were determined by using standard quantitative methods. The alkaloid content was gravimetrically determined by the method of Harborne (1998). The total phenolic and tannin contents were estimated and expressed as mg gallic acid equivalent (GAE)/g extract according to the method described by Siddhuraju and Becker (2003). The total flavonoids content was determined spectrophotometrically using a standard curve rutin as per the method of Zhishen et al. (1999) and expressed as mg rutin equivalent (RE)/g extract. Content of ascorbic acid was calculated on the basis of calibration curve of authentic L-ascorbic acid and the results were expressed as mg ascorbic acid equivalent (AAE) /g extract, proposed by Klein and Perry (1982). Total saponin content was determined by the method described by Makkar et al. (2007) with some modifications. The values were expressed as mg diosgenin equivalents (DE)/g extract.

\subsection{Determination of in vitro antioxidant activity}

\subsubsection{Reducing power assay}

The $\mathrm{Fe}^{3+}$ reducing power of the extract was determined according to the method suggested by Oyaizu (1986). The plant extracts $(300-700 \mu \mathrm{g} / \mathrm{mL})$ were mixed with $5.0 \mathrm{~mL}$ of $0.2 \mathrm{M}$ phosphate buffer of pH 6.6 and $5.0 \mathrm{~mL}$ of $1 \% \mathrm{~K}_{3} \mathrm{Fe}(\mathrm{CN})_{6}$ and the mixtures were incubated at $50^{\circ} \mathrm{C}$ for $20 \mathrm{~min}$. The reaction was terminated by adding $5.0 \mathrm{~mL}$ of $10 \%$ TCA (w/v), and the mixture was centrifuged at $1000 \mathrm{rpm}$ for $10 \mathrm{~min}$. The upper layer of the supernatant $(5.0 \mathrm{~mL})$ was mixed with $5.0 \mathrm{~mL}$ of distilled water and $1.0 \mathrm{~mL}$ of $0.1 \%(\mathrm{w} / \mathrm{v}) \mathrm{FeCl}_{3}$ and the absorbance was read at $700 \mathrm{~nm}$. Rutin, quercetin, BHA and BHT served as the reference materials. Increased absorbance indicates increased reductive capability.

\subsubsection{DPPH radical scavenging activity}

The hydrogen donating capacity was assessed using the stable DPPH ${ }^{\cdot}$ method (Blois, 1958). Briefly, a solution of $0.1 \mathrm{mM} \mathrm{DPPH}^{\bullet}$ was prepared using methanol. The samples (50-250

$\mu \mathrm{g} / \mathrm{mL}$ ) were mixed with $5.0 \mathrm{~mL}$ of $\mathrm{DPPH} \cdot$ solution. Reaction mixture was shaken, incubated at $27^{\circ} \mathrm{C}$ for $20 \mathrm{~min}$ and the absorbance was measured at 517 $\mathrm{nm}$. Results were compared with the activity of rutin, quercetin, BHA and BHT. Per cent DPPH • discolouration of the samples was calculated using the formula:

\section{DPPH radical scavenging activity $(\%)=[($ Control OD} - Sample OD) / Control OD] × 100.

Antioxidant activities of the extracts were expressed as $\mathrm{IC}_{50}$, these values were calculated from the linear regression of the percentage antioxidant activity versus concentration of the extracts. A lower $\mathrm{IC}_{50}$ value indicates greater antioxidant activity.

\subsubsection{Total antioxidant activity}

Total antioxidant activity was performed using an improved $\mathrm{ABTS}^{\circ}+$ method proposed by Siddhuraju and Manian (2007). The ABTS radical cation (ABTS ${ }^{\bullet}$ ) was generated by a reaction of $7 \mathrm{mM}$ $\mathrm{ABTS}^{*+}$ and $2.45 \mathrm{mM}$ potassium persulphate and the mixture was incubated for $12-16 \mathrm{~h}$ at room temperature in dark. Prior to assay, the solution was diluted in ethanol (about 1:89 v/v) and equilibrated to obtain an absorbance of $0.700 \pm 0.02$ at $734 \mathrm{~nm}$. $10 \mu \mathrm{L} / \mathrm{mL}$ of sample was added to $1.0 \mathrm{~mL}$ of diluted $\mathrm{ABTS}^{*+}$ solution. After $30 \mathrm{~min}$ of incubation, 
absorbance was read at $734 \mathrm{~nm}$. Trolox was used as a reference material.

\subsubsection{Inhibition of $\beta$ - carotene bleaching}

The antioxidant capacity of the extract was evaluated using $\beta$-carotene-linoleate model system (Taga et al., 1984).1mg of $\beta$ - carotene was dissolved in $10 \mathrm{~mL}$ of chloroform and mixed with $20 \mu \mathrm{L}$ of linoleic acid and $200 \mathrm{mg}$ of Tween - 40 emulsifier mixture. Chloroform was completely evaporated using rotary vacuum evaporator at $45^{\circ} \mathrm{C} .50 \mathrm{~mL}$ of oxygenated distilled water was added to the flask with vigorous shaking, to form an emulsion. $5 \mathrm{~mL}$ of emulsion was added to $100 \mu \mathrm{L}$ of sample from each tube, the zero-time absorbance was measured at 470 $\mathrm{nm}$. Subsequent absorbance readings were recorded at $15 \mathrm{~min}$ intervals by keeping the sample tubes in a water bath at $50^{\circ} \mathrm{C}$ until the colour of the control sample disappeared (about $120 \mathrm{~min}$ ). A blank, devoid of $\beta$ - carotene, was prepared for background subtraction. Rutin, quercetin, BHA and BHT were used as standards. $\beta$ - carotene bleaching activity was calculated as:

$\mathrm{AA}(\%)=\left[1-\left(\mathrm{A}_{s}{ }^{0}-\mathrm{A}_{\mathrm{s}}{ }^{120}\right) /\left(\mathrm{A}_{c}{ }^{0}-\mathrm{A}_{c}{ }^{120}\right)\right] \times 100$

Where, $A_{s}{ }^{0}$ - absorbance of sample at $0 \mathrm{~min}$, $A_{s}{ }^{120}$ - absorbance of sample at $120 \mathrm{~min}, \mathrm{~A}_{c}{ }^{0}$ absorbance of control at $0 \mathrm{~min}$, and $\mathrm{A}_{\mathrm{c}}{ }^{120}$ absorbance of control at $120 \mathrm{~min}$.

\subsubsection{Antihaemolytic activity}

Antihaemolytic activity was performed according to the method set forth by Naim et al. (1976). The erythrocytes from cow blood were separated by centrifugation (2000 rpm for $10 \mathrm{~min}$ ) and washed with saline phosphate buffer $(\mathrm{pH} 7.4)$ until the supernatant become colourless. The erythrocytes were then diluted with saline phosphate buffer to give $4 \%(\mathrm{v} / \mathrm{v})$ suspension. 500 $\mu \mathrm{g}$ of extract $/ \mathrm{mL}$ of saline phosphate buffer were added to $2.0 \mathrm{~mL}$ of erythrocytes suspension and made up to $5.0 \mathrm{~mL}$ with saline phosphate buffer. This mixture was pre-incubated for $5 \mathrm{~min}$ and then 0.5 $\mathrm{mL}$ of $\mathrm{H}_{2} \mathrm{O}_{2}$ solution of appropriate concentration in saline buffer was added. The concentration of $\mathrm{H}_{2} \mathrm{O}_{2}$ in the reaction mixture was adjusted so as to bring about $90 \%$ haemolysis of blood cells after 240 min. After the incubation time, the reaction mixture was centrifuged at $1500 \mathrm{rpm}$ for $10 \mathrm{~min}$ and the extent of haemolysis was determined by measurement of the absorbance (at $540 \mathrm{~nm}$ ) corresponding to haemoglobin liberation. Natural and synthetic standards at the same concentration as sample extract were used for comparison.
The percent haemolysis inhibition was calculated using the formula:

Inhibition percentage $=\left[\mathrm{A}_{\text {control }}-\mathrm{A}_{\text {sample }} / \mathrm{A}_{\text {control }}\right] \times 100$

Where, $A_{\text {control }}$ - absorbance of control and

$\mathrm{A}_{\text {sample }}$ - absorbance of sample.

\subsection{Statistical analysis}

All the values were expressed as mean \pm standard deviation (SD) of three determinations and subjected to one-way analysis of variance (ANOVA) followed by post hoc Duncan's multiple range test using SPSS (version 9, SPSS Inc., Chicago, USA). $P<$ 0.05 was chosen as the criterion for statistical significance.

\section{RESULTS}

The study revealed that the percent yield of methanolicextract was higher $(9.60 \%)$ followed by water extract (4.0\%). The other solvents viz., hexane, benzene and chloroform yielded very less quantity of residue only (Table 1 ).

\subsection{Qualitative estimations}

The major secondary metabolites present in the extracts were varied across the solvents used (Table 1). The methanolic extract of S. amplexicaulis tuber containing more number of secondary metabolites than the other extracts studied. Cardiac glycosides were present in all the alcoholic and aqueous extracts of tuber but resins, steroids, terpenoids and triterpenoids were totally absent in all the extracts. However, the degree of precipitation of phytochemicals varies in all the extracts.

\subsection{Quantitative estimations}

The quantity of phytochemicals estimated were varied among the extracts tested (Table 2).Among the six components, alkaloids $(92.02 \mathrm{mg} / \mathrm{g}$ dry powder) and saponins(39.4-135.8mg DE/g extract) contents were significantly higher and the tannins(0.01-1.57 mg GAE/g extract) content was very low when compared to the other compounds studied. Further, the degree of precipitation of secondary metabolites varies according to the extractive power of the solvents. Mostly the methanol extract contained high amount of secondary metabolites than the other solvents studied.

\subsection{In vitro antioxidant activities}

In the reducing power assay, the presence of antioxidants in the samples would result in the reduction of $\mathrm{Fe}^{3+}$ to $\mathrm{Fe}^{2+}$ by donating an electron which can be monitored by spectrophotometrically at $700 \mathrm{~nm}$. The reductive abilities displayed an 
apparent linear relationship with concentration. The chloroform extract showed higher reductive capability than the other extracts studied. The activity increases exponentially with the increase in concentration of sample. These values were compared with two natural (rutin and quercetin) and two synthetic (BHA and BHT) antioxidants (Fig. $1 \mathrm{a}$ and $1 \mathrm{~b})$.

$\mathrm{DPPH}^{\bullet}$, a stable organic radical, widely used to test the ability of compounds to act as free radical scavengers or hydrogen donors. It was visually noticeable by a colour change from purple to yellow. It possess concentration dependent scavenging activity. The $\mathrm{IC}_{50}$ values of the samples were ranging between 150.91 and $345.75 \mu \mathrm{g} / \mathrm{mL}$ and compared with standards as shown in Table 3.

In the evaluation of total antioxidant capacity by measuring ABTS ${ }^{*+}$ method, it is known that all the sample extracts were able to quench ABTS radical more effectively and the values were ranged between 2055.4 and $6226.8 \mu \mathrm{mol}$ Trolox equivalent/g extract. Among the samples investigated, hexane, methanol and water extracts showed maximum values $6129.0,6172.8$ and 6226.8 $\mu \mathrm{mol}$ Trolox equivalent/g extract respectively. On the other hand, the benzene and chloroform extracts registered markedly low ABTS radical scavenging activity (Table 3).

In $\beta$ carotene/linoleic acid bleaching assay it is known that all the extracts are having potential to inhibitthe peroxidation of linoleic acid and subsequent bleaching to $\beta$ carotenein various degrees. Apparently, the most effective extracts were benzene (97.85\%) and water (95.41\%). Furthermore, these values were comparatively higher than those of natural and synthetic antioxidants tested as shown in Fig. 2.

The protective effect of $S$. amplexicaulis tuber extracts and positive standards against $\mathrm{H}_{2} \mathrm{O}_{2}$ mediated haemolysis were investigated and presented in Fig. 3. In general, all the sample extracts contributed satisfactory antihaemolytic activity ranged between 34 and 53\%. Interestingly these values surpassed the efficiency of synthetic antioxidants, BHA (5\%) and BHT (7\%).

\section{DISCUSSION}

Many phytochemicals are now studied extensively for their potential ability of curing diseases. Herbal preparations are effectively and extensively used for their medicinal properties and have become increasingly popular worldwide. Standardization of crude drug is an integral part of establishing its correct identity. Qualitative and quantitative phytochemical screening of $S$. amplexicaulis tuber revealed that alkaloids, cardiac glycosides, flavonoids, glycosides, phenols, saponins, vitamin $\mathrm{C}$ and tannins were present in this plant. All the active compounds were excessively present in methanol extract (Table 1). Different solvents have been reported to have different capacity to extract phytoconstituents according to their solubility and polarity and most of the compounds dissolve well in high polar solvents (Karthika et al., 2014).

Table 1. Preliminary phytochemical screening of various extracts of Solena amplexicaulis tuber.

\begin{tabular}{|c|c|c|c|c|c|c|c|c|c|c|c|c|}
\hline \multirow{2}{*}{ Solvent } & \multirow{2}{*}{ Yield (\%) } & \multicolumn{11}{|c|}{ Phytoconstituents* } \\
\hline & & $\mathbf{A}$ & CG & $\mathbf{F}$ & G & $\mathbf{P}$ & $\mathbf{R}$ & $\mathbf{S}$ & St & $\mathbf{T}$ & Te & $\mathbf{T r}$ \\
\hline Hexane & 0.60 & - & - & - & - & - & - & +++ & - & - & - & - \\
\hline Benzene & 0.40 & - & - & - & - & - & - & ++ & - & - & - & - \\
\hline Chloroform & 0.17 & - & - & - & - & - & - & ++ & - & - & - & - \\
\hline Methanol & 9.60 & +++ & +++ & +++ & ++ & +++ & - & + & - & +++ & - & - \\
\hline Water & 4.00 & + & +++ & + & +++ & - & - & - & - & - & - & - \\
\hline
\end{tabular}

*A - Alkaloids; CG - Cardiac glycosides; F - Flavonoids; G - Glycosides; P - Phenols; R - Resins; S - Saponins; St - Steroids; T - Tannins; Te Terpenoids; Tr - Triterpenoids. +++ : highly present; ++ : moderately present; + : low, - : absent.

Table 2. Extractive yield, alkaloids, total phenolics, tannins, total flavonoids, vitamin $\mathrm{C}$ and saponinscontents of different solvent extracts of tuber of Solena amplexicaulis extracts.

\begin{tabular}{lccccc}
\hline \multicolumn{1}{c}{ Solvent } & $\begin{array}{c}\text { Total phenolics } \\
\text { (mg GAE/g } \\
\text { extract) }\end{array}$ & $\begin{array}{c}\text { Tannins } \\
\text { (mg GAE/g } \\
\text { extract) }\end{array}$ & $\begin{array}{c}\text { Total } \\
\text { flavonoids(mg } \\
\text { RE/g extract) }\end{array}$ & $\begin{array}{c}\text { Vitamin C } \\
\text { (mg AAE/g } \\
\text { extract) }\end{array}$ & $\begin{array}{c}\text { Saponins } \\
\text { (mg DE/g } \\
\text { extract) }\end{array}$ \\
\hline Hexane & $0.55 \pm 0.02^{\mathrm{a}}$ & $0.20 \pm 0.03^{\mathrm{b}}$ & Not detected & $0.069 \pm 0.46^{\mathrm{a}}$ & $135.8 \pm 0.56^{\mathrm{b}}$ \\
Benzene & $0.21 \pm 0.01^{\mathrm{a}}$ & $0.02 \pm 0.01^{\mathrm{a}}$ & Not detected & $0.032 \pm 0.25^{\mathrm{a}}$ & $121.5 \pm 0.27^{\mathrm{b}}$ \\
Chloroform & $0.17 \pm 0.01^{\mathrm{a}}$ & $0.01 \pm 0.02^{\mathrm{a}}$ & Not detected & $0.014 \pm 0.07^{\mathrm{a}}$ & $122.4 \pm 0.16^{\mathrm{b}}$ \\
Methanol & $6.32 \pm 0.18^{\mathrm{c}}$ & $1.57 \pm 0.47^{\mathrm{d}}$ & $8.94 \pm 0.21^{\mathrm{b}}$ & $0.666 \pm 0.76^{\mathrm{c}}$ & $55.6 \pm 0.13^{\mathrm{a}}$ \\
Water & $2.51 \pm 0.12^{\mathrm{b}}$ & $0.79 \pm 0.06^{\mathrm{c}}$ & $4.59 \pm 0.25^{\mathrm{a}}$ & $0.293 \pm 0.82^{\mathrm{b}}$ & $39.4 \pm 0.14^{\mathrm{a}}$ \\
\hline
\end{tabular}

Values are mean \pm standard deviation (SD) of three independent experiments.

Values not sharing a common letter in a column are significantly different $(P<0.05)$. 
Table 3. DPPH scavenging and total antioxidant activities of different solvent extracts of Solena amplexicaulis tuber.

\begin{tabular}{|c|c|c|}
\hline Solvents/Standards & $\begin{array}{c}\mathrm{IC}_{50} \text { values }(\mu \mathrm{g} / \mathrm{mL}) \\
\text { DPPH· scavenging activity }\end{array}$ & $\begin{array}{l}\text { Total antioxidant activity } \\
\text { ( } \mu \mathrm{mol} \text { of TE/g dry weight) }\end{array}$ \\
\hline Hexane & $345.75 \pm 0.14 \mathrm{e}$ & $6129.01 \pm 21.31^{\mathrm{b}}$ \\
\hline Benzene & $264.23 \pm 0.25^{d}$ & $2311.93 \pm 17.25^{\mathrm{a}}$ \\
\hline Chloroform & $214.12 \pm 0.11^{c}$ & $2055.45 \pm 15.42^{\mathrm{a}}$ \\
\hline Methanol & $150.91 \pm 0.18^{b}$ & $6172.81 \pm 29.36^{b}$ \\
\hline Water & $238.15 \pm 0.29^{c}$ & $6226.87 \pm 23.51^{c}$ \\
\hline Rutin & $15.75 \pm 0.01^{\mathrm{a}}$ & - \\
\hline Quercetin & $20.71 \pm 0.04^{a}$ & - \\
\hline BHA & $21.41 \pm 0.11^{\mathrm{a}}$ & - \\
\hline BHT & $34.74 \pm 0.26 \mathrm{a}$ & - \\
\hline
\end{tabular}

Values are mean \pm standard deviation (SD) of three independent experiments.

Values not sharing a common letter in a column are significantly different $(P<0.05)$.

The reducing power of a compound may serve as a significant indicator for potential antioxidant activity. Reducing properties are generally associated with the presence of reductones. The presence of reductones in sample extracts might cause the reduction of the $\mathrm{Fe}^{3+} /$ ferric cyanide complex to $\mathrm{Fe}^{2+}$ /ferrous form which can be monitored by measuring the formation of Perl's Prussian blue with absorbance at $700 \mathrm{~nm}$. The study revealed that the methanolic extract of $S$. amplexicaulis tuber due to the presence of reductones might significantly contribute the antioxidant activity (Singhal et al.,2011).

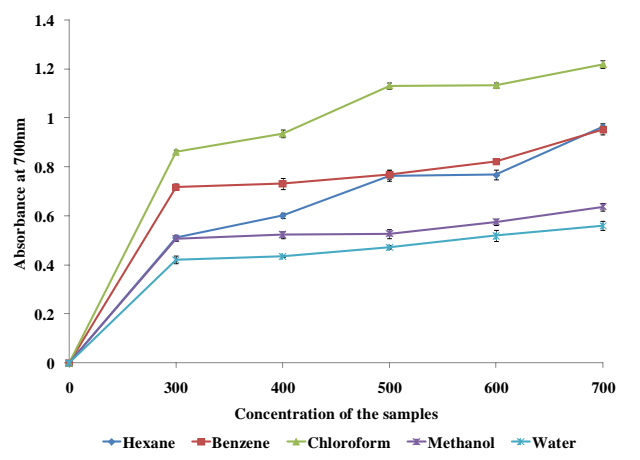

Fig. 1a. Reducing ability of different extracts of Solena amplexicaulis tuber. Values are mean \pm standard deviation (SD) of three independent experiments.

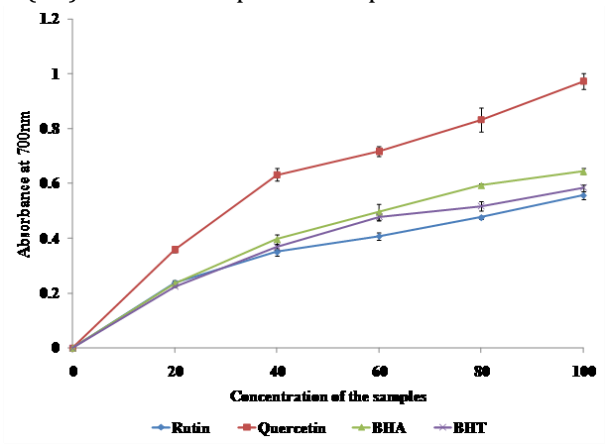

Fig. 1b. Reducing ability of natural and synthetic antioxidants. Values are mean \pm standard deviation (SD) of three independent experiments.

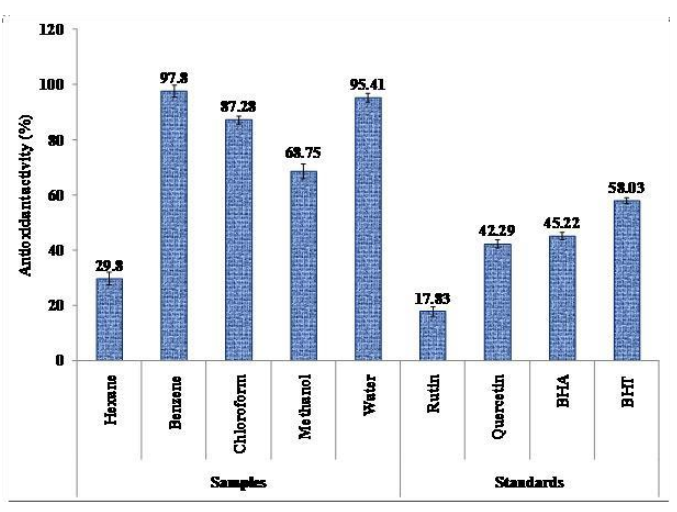

Fig. 2. Lipid peroxidation preventive property of tuber extracts of Solena amplexicaulis with certain standardsin $\beta$ - carotene linoleic acid system. Values are mean \pm standard deviation (SD) of three independent experiments.

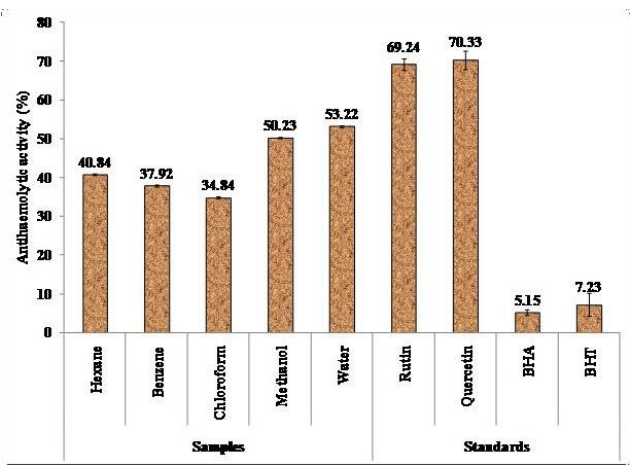

Fig. 3. Antihaemolytic property of tuber extracts of Solena amplexicaulis compared with certain standards. Values are mean \pm standard deviation (SD) of three independent experiments.

DPPH is a stable free radical and accepts an electron or hydrogen radical to become a stable molecule. Antioxidants in the sample on interaction with $\mathrm{DPPH}^{\bullet}$, transfer electron to $\mathrm{DPPH}^{\bullet}$ and thus neutralizing its free radical character and convert it to 1-1 diphenyl-2-picryl hydrazine and the degree of discoloration (purple to yellow) indicates the scavenging activity of the drug (Apak et al., 2013). 
The results of $\mathrm{DPPH}$-scavenging assay indicate that the methanolic plant extract possess high antioxidant activity (Table 3). The extracts showed a significant correlation with total phenolics, tannins and total flavonoids content $\left(\mathrm{R}^{2}=0.972, \mathrm{R}^{2}=0.952\right.$ and $\mathrm{R}^{2}=0.953$ respectively) and partially correlation with alkaloids and saponins $\left(\mathrm{R}^{2}=0.822\right.$ and $\mathrm{R}^{2}=0.890$ respectively). This high potential of phenolic compounds to scavenge radicals may be explained by their phenolic hydroxyl groups, in addition to synergistic effects of the compounds present in this plant species (Noguer et al., 2014).

ABTS $^{\bullet+}$ (protonated radical) is a blue chromophore produced by the reaction between ABTS and potassium persulphate (Ruby et al., 2009). The characteristic absorbance maxima is at $734 \mathrm{~nm}$. The presence of bioactive chemical compounds in the tested extracts that inhibit the potassium persulphate activity may reduce the production of ABTS $^{\bullet+}$. From the results, the aqueous extract of $S$. amplexicaulis tuber possessed the highest ABTS ${ }^{\bullet+}$ scavenging activity. Thus, it might be speculated that the antioxidant activity of the extract may be possibly attributed to the phytochemicals present in it. Further the extract also demonstrated a high correlation with total phenolics and vitamin $\mathrm{C}$ content $\left(\mathrm{R}^{2}=0.991\right.$ and $\mathrm{R}^{2}=0.986$ respectively).

In the $\beta$ carotene bleaching assay, the oxidation of linoleic acid generates peroxyl free radicals due to the abstraction of a hydrogen atom from diallylic methylene groups of linoleic acid. The free radicals well then oxidize the highly unsaturated $\beta$ carotene. The presence of antioxidants in the sample will minimize the oxidation of $\beta$ carotene by hydroperoxides. Hydroperoxide formed in this system will be neutralized by the antioxidants from the samples. Thus the degradation rate of $\beta$ carotene depends on the antioxidant activity of the sample (Chakraborty and Verma, 2010). In the present study all the extracts inhibited peroxidation of linoleic acid and subsequent bleaching to $\beta$ carotene in various degrees. The extracts showed a significant correlation with total phenolics $\left(\mathrm{R}^{2}=0.999\right)$, tannins $\left(\mathrm{R}^{2}=0.993\right)$ and vitamin $\mathrm{C}\left(\mathrm{R}^{2}=0.988\right)$ contents. Therefore, it can be explained that the $\beta$ carotene bleaching assay of the studied plant extracts may be attributed to the presence of phenolics, tannins and vitamin $\mathrm{C}$ in them.

Erythrocytes are considered as major targets for the free radicals which are potent promoters of activated oxygen species. The red blood cells were treated with hydrogen peroxide $\left(\mathrm{H}_{2} \mathrm{O}_{2}\right)$ the haemolysis was done. This could be attributed to the oxidizing nature of $\mathrm{H}_{2} \mathrm{O}_{2}$. In the present study lipid oxidation of cow blood erythrocyte membrane mediated by $\mathrm{H}_{2} \mathrm{O}_{2}$ induces membrane damage and subsequently haemolysis (Dai et al., 2006). Among the plant samples investigated, benzene and water extracts have higher antihaemolytic activity. Dai et al. (2006) also recorded that flavonols and their glycosides are competent antioxidants which are capable of protecting human red blood cells against oxidative haemolysis stimulated by free radical. The extracts demonstrated a high correlation with total phenolics $\left(\mathrm{R}^{2}=0.980\right)$, tannins $\quad\left(\mathrm{R}^{2}=0.967\right)$, flavonoids $\left(\mathrm{R}^{2}=0.862\right)$ and vitamin $\mathrm{C}\left(\mathrm{R}^{2}=0.932\right)$ content. The statistical analysis using the Pearson tests indicated a positive linear correlation between the secondary metabolites and antioxidant assays, in agrees with other reports (Ebrahimzadeh et al., 2014; Ghasemi et al., 2014). The analyses were statistically significant $(\mathrm{P}<0.05)$, showing correlation coefficients greater than 0.748 in this test.

\section{CONCLUSION}

Based on the active profile exposed through various assays, it can be concluded that major secondary metabolites identified in $S$. amplexicaulistuber are playing pivotal role in the scavenging of radicals and hence the better antioxidant activity. Hence it is a promising natural source of antioxidant can be used in nutritional or pharmaceutical fields for the prevention of free radical medicated diseases. However, pharmacognostical studies are suggested to confirm the antioxidant ability before going for commercialization.

\section{ACKNOWLEDGMENT}

The authors graciously acknowledge the financial support given by University Grants Commission, New Delhi (Grant No. F. 41$415 / 2012(\mathrm{SR})$ ) to carry out the work.

\section{REFERENCES}

Abdolbaset, G., L. Gerhard, F. Liu and S. Joachim, (2011). Ethnobotanical study of medicinal plants utilised by Hani ethnicity in Naban River Watershed National Nature Reserve, Yunnan, China. J. Ethnopharmacol 134: 651-667.

Apak, R., S. Gorinstein, V. Bohm, K.M. Schaich, M. Ozyurek and K. Guclu, (2013). Methods of measurement and evaluation of natural antioxidant capacity/activity (IUPAC Technical Report). Pure Appl. Chem 85: 957-998.

Arun, Ch., R. Satheesh Kumar, S. Srinu, G. Lal Babu, G. Raghavendra Kumar and J. Amos Babu, (2011). Antiinflammatory activity of aqueous extract of 
leaves of Solena amplexicaulis. Int. J. Res. Pharm. Biomed. Sci 2: 1617-1619.

Blois, M.S. (1958). Antioxidant determinations by the use of a stable free radical. Nature 181: 1199. 1200.

Carlsen, M.H., B.L. Halvorsen, K. Holte, S.K. Bohn, S. Dragland, L. Sampson, et al. 2010. The total antioxidant content of more than 3100 food, beverages, spices, herbs and supplements used worldwide. Nutrition J 9: 3.

Dai, F., Q. Miao, B. Zhou, L. Yang and Z.L. Liu, (2006). Protective effect of flavonols and their glycosides against free radical - induced oxidative hemolysis of red blood cells. Life Sci 78: $2488-2493$.

Chakraborty, D. and R. Verma, (2010). Ameliorative effect of Emblica officinalis aqueous extract against ochratoxin - induced lipid peroxidation in the kidney and liver of mice. Int. J. Occup. Med. Environ. Health 23: 63-73.

Dezfuli, N.M., S. Saeidnia, A.R. Gohari and M.K. Mohmoodabadi, (2014). Phytochemistry and pharmacology of Berberis species. Pharmacogn. Rev 8: 8-15.

Dhananjay, J.D. (2006). Handbook of medicinal herbs, Agrobios, Jodhpur, India.

Ebrahimzadeh, M.A., R. Enayatifard, M. Khalili, M. Ghaffarloo, M. Saeedi and J.Y. Charati, (2014). Correlation between sun protection factor and antioxidant activity, phenol and flavonoid contents of some medicinal plants. Iran. J. Pharm. Res 13: 1041-1047.

Ghasemi, A.P., A. Siahpoosh, M. Setayesh and L. Craker, (2014). Antioxidant activity, total phenolic and flavonoid contents of some medicinal and aromatic plants used as herbal teas and condiments in Iran. J. Med. Food 17: 1151-1157.

Harborne, J.B. (1998). Phytochemical Methods, A guide to modern techniques of plant analysis. $3^{\text {rd }}$ (eds.), Chapman and Hall, London, UK.

Jeyaprakash, K., M. Ayyanar, K.N. Geetha and T. Sekar, (2011). Traditional uses of medicinal plants among the tribal people in Theni District (Western Ghats), Southern India. Asian Pac. J. Trop. Biomed 1: 20-25.

Karthika, K., S. Paulsamy and S. Jamuna, (2012). Evaluation of in vitro antioxidant potential of methanolic leaf and stem extracts of Solena amplexicaulis (Lam.) Gandhi. J. Chem. Pharm. Res 4: 3254-3258.

Karthika, K., K. Thenmozhi, S. Paulsamy and S. Manian, (2014). Quantificantion of phytochemicals and in vitro antioxidant potential of various solvent extracts of certain species of Acanthaceae. Int. J. Green Pharm 5864.

Klein, B.P. and A.K. Perry, (1982). Ascorbic acid and Vitamin A activity in selected vegetables from different geographical areas of the United States. J. Food Sci 47: 941-945.

Makkar, H.P.S., P. Siddhuraju and K. Becker, (2007). Methods in molecular biology: Plant secondary metabolites. Humana Press Inc., Totowa, NJ, USA.

Matthew, K.M. (1983).The flora of the Tamil Nadu Carnatic, Part I. Polypetalae.The Rapinet Herbarium St. Josepj's College, Tiruchirapalli, India.

Mohammed, R., C. Paritosh, P. Alok Kumar, N. Dilruba, A. Rasheda, J.F. Farhana, et al. 2011.A survey of preventive medicinal plants used by the Chakma residents of Hatimara (south) village of Rangamati district, Bangladesh. Am. Eurasian J. Sustain. Agric 5: 92-96.

Naim, M., B. Gestener, A. Bondi and Y. Birk, (1976). Antioxidative and antihemolytic activities of soyabeanisoflavones. J. Agric. Food Chem 24: 1174-1177.

Noguer, M., A.B. Cerezo, M.L. Moya, A.M. Troncoso and M.C.G. Parrilla, (2014). Synergism effect between phenolic metabolites and endogenous antioxidants in terms of antioxidant activity. Adv. Chem. Engin. Sci 4: 258-265.

Oyaizu, M. (1986). Studies on products of browning reactions.Antioxidative activities of products of browning reaction prepared from glucosamine. Jpn. J. Nut. Diet 44: 307-315.

Paulsamy, S. and K. Karthika, (2014). Distribution and density of the climber, Solena amplexicaulis (Lam.) Gandhi. in certain dry deciduous forests of southern Western Ghats, India. Int. J. Ecol. Dev 28: 63-78.

Ruby, G., S. Mukta, L. Ramakrishnan, P. Dorairaj and K.R. Srinath, (2009). Improved method of total antioxidant assay. Indian J. Biochem. Biophys 46: 126-129.

Servili, M., B. Sordini, S. Esposto, S. Urbani, G. Veneziani, I.D. Maio, R. Selvaggini and A. 
Taticchi, (2014). Biological activities of phenolic compounds of extra virgin olive oil. Antioxidants 3: 1-23.

Siddhuraju, P. and K. Becker, 2003.Antioxidant properties of various solvent extracts of total phenolics constituents from three different agroclimatic origins of drumstick tree leaves (Moringa oleifera Lam.) leaves. J. Agric. Food Chem 51: 2144-2155.

Siddhuraju, P. and S. Manian, (2007). The antioxidant activity and free radical scavenging capacity of dietary phenolic extracts from horse gram (Macrotyloma uniflorum (Lam.) Verdc.) seeds. Food Chem 105: 950-958.

Singhal, M., A. Paul, H.P. Singh, S.K. Dubey and K. Gaur, (2011). Evaluation of reducing power assay of chalconesemicarbazones. J. Chem. Pharm. Res 3: 639-645.
Taga, M.S., E.E. Miller and D.E. Pratt, 1984. Chia seeds as a source of natural lipid antioxidants. J. Am. Oil Chem. Soc 61: 928-931.

Trease, G. and S.M. Evans, (2002). Pharmacognosy.15th (eds.), Bailer Tindal, London.

Venkateshwaralu, E., A. Raghuram Reddy, P. Goverdhan, K. Swapna Rani and G. Jayapal Reddy, (2011). In vitro and in vivo antioxidant activity of methanolic extract of Solena amplexicaulis (whole plant). Int. J. Pharm. Biol. Sci 1: 522-533.

Zhishen, J., T. Mengcheng and W. Jianming, (1999). The determination of flavonoids contents in mulberry and their scavenging effects on super oxides radicals. Food Chem 64: 555-559. 